\title{
Optical signatures of seawater and potential use for verification of mid-ocean ballast water exchange
}

\author{
Carlton D. Hunt ${ }^{1, *}$, Deborah Tanis ${ }^{1}$, Elizabeth Bruce ${ }^{1}$, Michael Taylor ${ }^{2}$ \\ ${ }^{1}$ Battelle, 397 Washington Street, Duxbury, Massachusetts 02332, USA \\ ${ }^{2}$ Cawthron Institute, Private Bag 2, Nelson, New Zealand
}

\begin{abstract}
Mandatory requirements for exchange of ships' ballast water in the open ocean require an effective means of verifying that open ocean exchange has occurred. This study demonstrates that UV fluorescence of chromophoric organic matter in seawater has great potential to verify open ocean ballast water exchange. Ballast water samples, obtained for excitation-emission spectral analysis during 2 flow-through ballast water exchange events in the trans-Pacific voyage of a chemical carrier, establish a clear difference between the UV fluorescence characteristics of ballast water before and after mid-ocean exchange. The exchange of water in mid-ocean shifted the fluorescence signatures of ballast water from those typical of the coastal water at the donor ports to those of the exchanged mid-ocean water. Estimates based on the fluorescence data suggest that at least $90 \%$ of the coastal water was exchanged. The shifts in fluorescence intensity and structure were concomitant with a $>99 \%$ reduction in the concentration of tracer dye added to the ballast tanks during ballasting in the ports of origin. In contrast, changes in phytoplankton and zooplankton species composition and diversity were not as great, which limit their potential for verification of mid-ocean exchange. The consistently low fluorescence intensity and lack of fluorescence structure of mid-Pacific ocean water relative to the coastal waters, and the stability of the fluorescence in the ballast tanks before and after exchange, suggest that fluorescence techniques can form the basis of verifying the presence of open ocean water in ballast tanks.
\end{abstract}

KEY WORDS: Ballast water exchange - Aquatic nuisance species - Non-indigenous species · Coloured dissolved organic matter · CDOM · UV fluorescence

\section{INTRODUCTION}

The introduction of non-indigenous aquatic nuisance species (ANS) to coastal areas around the world has had profound negative impacts on aquatic ecosystems (Carlton et al. 1995, National Research Council 1996, Ruiz et al. 2000,) and is considered to be one of the most important environmental issues facing the maritime community (USCG 2001). Non-indigenous species (NIS) introductions have been cited as the second greatest threat to biodiversity behind habitat loss (Vitousek et al. 1997) and are recognized by conservation biologists (www.gao.gov/atext/d031089r.txt) as the second most serious threat to endangered species after habitat destruction. The introduction of ANS has altered important ecological processes and caused serious economic damage worldwide.

A primary vector for the introduction of marine nonnative species is through discharge of ballast water from ships. Ballast water is used to increase the stability, maneuverability, and safety of ocean-going ships. The ballast tanks of a vessel are typically filled with water from the port of origin and emptied of that water at the destination port, potentially leading to the transport of unwanted, non-native species from one port to the other.

Regulatory actions have been implemented worldwide to prevent and control the introduction of NIS via ballast water discharge. Originally, many of these actions were voluntary, including the US Coast 
Guard's (USCG) guidelines that all vessels entering US waters after operating outside of the exclusive economic zone (EEZ) conduct ballast water management (BWM) including voluntary ballast water exchange. However, the US Secretary of Transportation reported in 2002 that approximately $74 \%$ of all regulated vessels failed to comply with voluntary BWM and concluded that compliance with the voluntary guidelines was insufficient to allow for an accurate assessment of the voluntary BWM guidelines (USCG 2001).

Adherence to the voluntary guidelines was not found to be effective for vessels entering US ports so the USCG published a rule in 2004 that makes BWM mandatory for all vessels that are equipped with ballast water tanks and are entering US waters from outside the EEZ (USCG 2004). The mandatory requirements included 'Exchange ballast water beyond the EEZ, in an area more than 200 nautical miles from any shore', 'retention of ballast water on board', or that vessels 'Use an 'environmentally sound' US Coast Guard-approved alternative ballast water management method before the vessel enters the US EEZ' (USCG 2004). Moreover, the recently adopted 'International Convention for the Control and Management of Ships Ballast Water \& Sediments' (International Maritime Organization 2004) calls for alternative ballast water management practices and requires exchange at sea. Thus, until such time that alternative ballast water management methods are approved and become widespread, exchange of ballast water at sea will be the primary means of reducing the risk of invasive species introduction.

The concept behind ballast water exchange is replacement of all or most of the original ballast water from a port of origin with water from mid-ocean, in order to minimize the risk of trans-oceanic transfer of unwanted species (Hay \& Tanis 1998). There are 2 main methods of making mid-ocean exchanges: reballasting and flow-through dilution. Reballasting involves completely emptying then refilling the ballast tank (for container vessels) or ballast hold (for bulk carriers). The flow-through dilution method requires pumping ocean water into the ballast tank or ship's hold and allowing water to overflow. Rigby \& Hallegraeff (1994) calculated that if a water volume equal to 3 times the ballast tank volume is pumped through the tank, $95 \%$ of the original coastal water in a ballast tank should be replaced.

Exchange operations which aim to exchange at least $95 \%$ of the original ballast water also aim to kill or remove at least $95 \%$ of the organisms in that water. However, dilution of the original water is not the same as the removal of the organisms as there are indications of plankton retention in ballast tanks during exchanges. For example, Rigby \& Hallegraeff (1994) found that while a completed exchange carried out under static conditions (i.e. the vessel was anchored in Singapore Harbour) resulted in the retention of $5 \%$ of the original water, $25 \%$ of the original phytoplankton material remained. Similarly, Harvey et al. (1999) reported that mid-ocean exchange greatly reduces the diversity and abundance of planktonic organisms in the ballast water of ships entering the Great Lakes. The presence of coastal species in incoming vessels that had reported complete exchanges suggests that the exchanges were incomplete and suggest the biota may be retained in the tanks either by entrainment or sedimentation, or by avoiding the outlets, in the case of larger species. Taylor \& Bruce (1999) found moderate to high biological exchange in a series of ballast water exchange studies on a vessel conducting exchange at sea in the Pacific Ocean, even when dye tracer studies demonstrated $>99 \%$ exchange of coastal water with ocean water. Even so, until more effective BWM methods are available, exchange at sea is the best widely available method of reducing the risk of invasive species introductions via ballast water.

Given this, managers who regulate ballast water are faced with verification of ships' compliance with midocean exchange regulations. One verification method practiced widely is measurement of salinity. However salinity suffers from lack of specificity and is variable within a small range across the world's oceans, thus its utility for verifying exchange is limited except for ports of origin with low salinity water (Taylor \& Bruce 1999). Verification methods that either supplement or replace the salinity measurements are required to accurately discriminate open-ocean water from coastal water.

In anticipation of the regulatory needs for robust, specific verification methods that are easily deployed in the receiving ports, we explored several potential verification approaches. One of the potential approaches identified was the structure of dissolved organic matter (DOM), which occurs at different concentrations and is also compositionally different between the open ocean and coastal waters (Coble et al. 2004). DOM in natural waters has been referred to as fulvic acid, gelbstoff, yellow substance, and humic substances (Kirk 1983). A major source of gelbstoff in coastal regions is river runoff, which includes terrestrial humic and fulvic acids (Coble \& Brophy 1994). Other sources that contribute to DOM in the coastal environment include wastewater discharges, marshes, and wetlands. DOM concentration varies significantly depending upon the original source of the matter and its components depend on the specific water body in question. Typically, DOM concentrations decrease from freshwater to coastal to marine environments, and tend to be highest in coastal regions and harbours, owing to the proximity of terrestrial sources (Coble et 
al. 2004). DOM decreases in concentration further offshore, where the sources of DOM are greatly reduced. Marine organic matter is primarily derived from the decomposition of marine organisms such as phyto- and zooplankton: when these organisms die, decomposition processes produce a complex of coloured organic matter.

One of the distinctive properties of coloured DOM is fluorescence in the ultraviolet and blue regions of the light spectrum. Two distinct types of fluorescence signal attributable to DOM have been identified in seawater: a humic-like fluorescence and a protein- or amino acid-like fluorescence (Coble 1996). It is possible to use these fluorescence signatures to identify different types of DOM using excitation-emission matrix (EEM) spectra. EEM spectra show characteristic excitation/emission maxima $\left(\mathrm{Ex}_{\max } / \mathrm{Em}_{\max }\right)$ for different water types. Average wavelengths for these maxima for different water types have been shown to be: rivers $\mathrm{Ex}_{\max } / \mathrm{Em}_{\max }=340 / 48 \mathrm{~nm}_{i}$ coastal water $\mathrm{Ex}_{\max } / \mathrm{Em}_{\max }=$ $342 / 442 \mathrm{~nm}$; marine shallow transitional $\mathrm{Ex}_{\max } / \mathrm{Em}_{\max }=$ $310 / 423 \mathrm{~nm}$; marine shallow entropic $\mathrm{Ex}_{\max } / \mathrm{Em}_{\max }=$ 299/389 $\mathrm{nm}$; and marine deep water $\mathrm{Ex}_{\max } / \mathrm{Em}_{\max }=$ $340 / 438 \mathrm{~nm}$ (Coble 1996). These average maxima demonstrate that fluorescence characteristics of water types differ and suggest that the specificity of the spectra was potentially useful for verifying mid-ocean ballast water exchange.

The objective of this study was to assess whether fluorescence measurements of seawater were useful for identifying different water types in ballast tanks during exchange at sea on a commercial vessel and to assess whether the method could be used to verify mid-ocean ballast water exchange. To ensure that the efficiency of the exchange was known, a tracer dye (Rhodamine WT) was used as a comparative measure of dilution efficiency while the ballast water was exchanged. The biological effectiveness of the exchange was also examined (Taylor \& Bruce 1999).

\section{MATERIALS AND METHODS}

Experimental design. Ballast water exchange trials were carried out during a voyage of the MT 'Iver Stream' from Kawasaki Harbour, Japan to Singapore Harbour (first transect: 23 February to 8 March 1999) and from Singapore Harbour to New Plymouth, New Zealand (second transect: 8 to 24 March 1999). The MT 'Iver Stream' is a methanol carrier that plies a regular trans-Pacific route between New Zealand, Japan and other parts of Asia, and arrives in New Zealand fully ballasted. It has a dead-weight (i.e. weight of cargo that can be carried) of 35273 short tons (Taylor \& Bruce 1999), equivalent to 32000 metric tonnes.
The ship's track-line and the location of ballast water exchanges and mid-ocean sampling during the voyage are shown in Fig. 1. At each of the donor ports (Kawasaki Harbour and Singapore Harbour) and during the voyage, ballast water and ocean water were collected for measuring the dilution efficiency (dye and salinity), optical characteristics of coastal, ocean, exchanged water, and changes in plankton communities (Taylor \& Bruce 1999).

The MT 'Iver Stream' has 2 pairs of port and starboard ballast tanks (capacity: $\sim 1434 \mathrm{~m}^{3}$ each; depth: $15 \mathrm{~m}$; width: $6.5 \mathrm{~m}$; length: $14.5 \mathrm{~m}$ ). Although the ballast tanks were not compartmentalized they contained internal platforms and framing structures and a ladder that allowed access to all levels. All mid-ocean exchanges were carried out using the flow-through dilution method (maximum pump rate: $170 \mathrm{~m}^{3} \mathrm{~h}^{-1}$ ). The vessel traveled approximately 900 to $1200 \mathrm{~km}$ during the time it took to exchange 3 times the volume of 1 ballast tank, i.e. over 24 to $40 \mathrm{~h}$, depending on the pumps that were available. All ballast water samples were collected via Butterworth hatches located on the seaward side of the top of the tanks.

At the beginning of the first transect (23 February 1999) all 4 ballast tanks were completely emptied and then cleaned of the remaining sediments prior to filling in Kawasaki Harbour. The objective of cleaning the tanks was to minimize the level of interference of the fluorescence intensity measurements used for the optical characteristic studies. During filling, the seawater depth was approximately $10 \mathrm{~m}$ and the ballast water intake was at approximately $7 \mathrm{~m}$ below the harbour's surface. The Rhodamine WT dye was added as the tanks filled to achieve a nominal $0.1 \mathrm{ppm}$ concentration. The final dye concentration in the tanks was determined from samples collected from multiple depths using standard fluorescence methods.

On the first transect, the first exchange was carried out in the East China Sea (approximate depth: $6400 \mathrm{~m}$ ) from 26 to 28 February 1999 using the port ballast tank (Tank 6P). The second exchange was carried out in the South China Sea (approximate depth: $3700 \mathrm{~m}$ ) from 1 to 2 March 1999, using the starboard ballast tank (Tank 6S). The second port ballast tank (Tank 7P) was used as a non-exchanged control for both exchanges. The second starboard ballast tank (Tank 7S) was intended as a second control; however, this tank was not completely filled in Kawasaki Harbour and was subsequently 'contaminated' by coastal water uplifted off the coast of Japan several hours after departure. Consequently, this tank was only used for assessing the stability of the optical signature. For both exchanges on the first transect, ocean water was pumped in through 4 to 6 large deck hoses into the man-hole at the top of the tank and out via another 


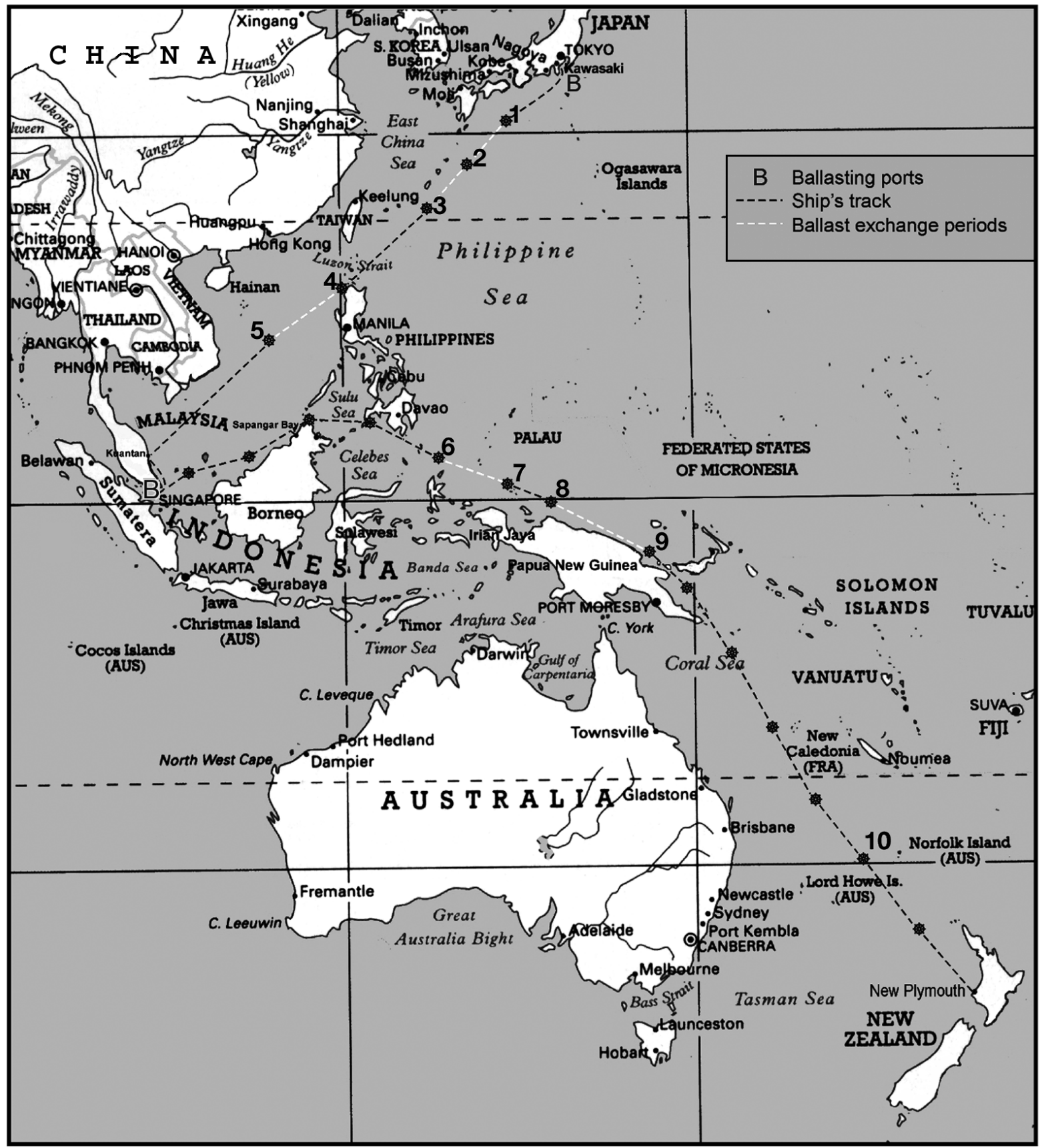

$131^{\circ} 27^{\prime} \mathrm{N} 135^{\circ} 40^{\prime} \mathrm{E}$ Start exchange tank 6 port, (26/2/99) Mid-ocean sample pt

$227^{\circ} 25^{\prime} \mathrm{N} 131^{\circ} 13^{\prime} \mathrm{E} \quad$ Mid-ocean sample pt $(27 / 2 / 99)$

$323^{\circ} 20^{\prime} \mathrm{N} 126^{\circ} 20^{\prime} \mathrm{E}$ End exchange tank 6 port $(28 / 2 / 99)$

$418^{\circ} 50^{\prime} \mathrm{N} 120^{\circ} 29^{\prime} \mathrm{E}$ Start exchange tank 6 starboard $(1 / 3 / 99)$

$513^{\circ} 06^{\prime} \mathrm{N} 114^{\circ} 13^{\prime} \mathrm{E}$ End exchange tank 6 starboard $(2 / 3 / 99)$ $63^{\circ} 54^{\prime} \mathrm{N} 128^{\circ} 28^{\prime} \mathrm{E}$ Start exchange tank 6 port $(13 / 3 / 99)$

$701^{\circ} 13^{\prime} \mathrm{N} 134^{\circ} 25^{\prime} \mathrm{E}$ End exchange tank 6 port, (14/3/99) Mid-ocean sample pt

$800^{\circ} 17^{\prime} \mathrm{N} 138^{\circ} 57^{\prime} \mathrm{E} \quad$ Start exchange tank 6 starboard $(15 / 3 / 99)$

$905^{\circ} 29^{\prime} \mathrm{S} 146^{\circ} 26^{\prime} \mathrm{E}$ End exchange tank 6 starboard $(17 / 3 / 99)$

$1028^{\circ} 35^{\prime} \mathrm{S} 165^{\circ} 56^{\prime} \mathrm{E} \quad$ Mid-ocean sample pt $(22 / 3 / 99)$

Fig. 1. Voyage of the MT 'Iver Stream' from Japan to New Zealand, 22 February to 24 March 1999, showing locations of mid-ocean ballast water exchanges and mid-ocean sampling points 
pump at the bottom of the tank, near the aft end. Three tank volumes were exchanged.

At the beginning of the second transect (8 March 1999) the ballast tanks were partly filled with Singapore Harbour water. The filling was completed as the vessel travelled out of the harbour (between $01^{\circ} 20^{\prime} \mathrm{N}$ $103^{\circ} 50^{\prime} \mathrm{E}$ and $02^{\circ} 26^{\prime} \mathrm{N} 106^{\circ} 56^{\prime} \mathrm{E}$ ). The first exchange was made in the west Pacific off the east coast of West Papua (approximate depth: $1400 \mathrm{~m}$ ) from 13 to 14 March 1999, using one port ballast tank (Tank 6P). The second exchange was made off the north coast of Papua New Guinea (depth: 900 to $2000 \mathrm{~m}$ ) from 15 to 17 March 1999, using one starboard tank (Tank 6S). The first exchange was complete. However, the second exchange was equal to only 2 times the tank volume, owing to vessel time constraints. For both exchanges on the second transect, the water was pumped in at the bottom, near the aft end of the tanks, and allowed to overflow out of the hatches described above.

The sampling program on the first transect consisted of samples collected from Kawasaki Harbour, the mid-ocean during exchanges, and ballast water samples collected from both of the exchange and control tanks. The ballast tanks were initially sampled several hours after uplifting ballast in Kawasaki Harbour, several hours before and after exchanges, and at the end of the transect in Singapore Harbour. Kawasaki Harbour water remained in the control tanks for the entire transect, and so traversed a wide latitudinal range from temperate regions to the tropics (Fig. 1). It was therefore subjected to considerable variation in temperature.

Fluorescence analyses of samples collected during the second transect was limited. During the second exchange on the second transect, the vessel sailed in close proximity (10 to $15 \mathrm{~km}$ ) to the mouth of the Sepik River, hence the results of this exchange were of special interest with respect to changes in salinity and the composition of plankton communities within the tank. No control tank was available for this exchange, however, due to cargo loading constraints. Data not presented in this paper can be found in Taylor \& Bruce (1999).

Sample collection. Unfiltered coastal and ballast water samples $(500 \mathrm{ml})$ were collected for fluorescence analysis using a $5 \mathrm{l}$ van Dorn sampler. Mid-ocean surface water samples were collected using a stainless steel bottle, which was cast into the sea from the vessel's foredeck. Separate samples for fluorescence and dye analysis were taken from each sampler. Duplicate samples were collected from mid-water strata of the ports and also ballast water tanks from the van Dorn bottle to assess variation in the analytical method. At the end of each transect the samples for fluorescence analysis were shipped to Battelle. All water samples were stored in the dark at $4^{\circ} \mathrm{C}$ in amber polyethylene bottles until analyzed, typically within 30 to $45 \mathrm{~d}$ of col- lection. Water samples were not filtered, as we believe the unfiltered water more accurately reflects what might be encountered in a compliance verification program. This would typically be conducted under tight sample collection timelines, would not have the luxury of filtering samples in the field, and could, in concept, rely on optical probes to perform the fluorescence measurement.

Fluorescence measurements. High-resolution EEM spectra were obtained with a SPEX Fluorolog 2 Spectrofluorometer. Measurements were performed at the University of Massachusetts, Boston. Samples were lightly shaken and the sampling bottle inverted several times to ensure a homogenous mixture; they were then poured into a clean $1 \mathrm{~cm}$ quartz cuvette for analysis. Excitation wavelengths ranged from 220 to $400 \mathrm{~nm}$ at a wavelength increment of $5 \mathrm{~nm}$ and a bandwidth of $4 \mathrm{~nm}$. The emission wavelengths ranged from 250 to $550 \mathrm{~nm}$ at an increment of $2 \mathrm{~nm}$ and a bandwidth of $4 \mathrm{~nm}$. The instrument integration time was set at $0.5 \mathrm{~s}$. The time required to complete all 37 emission scans on a sample was approximately $1.5 \mathrm{~h}$. All fluorescence measurements were performed at $20^{\circ} \mathrm{C}$. The region of interest is shown in Fig. 2.

For the selected excitation wavelength range (220 to $400 \mathrm{~nm}$ ) the individual excitation and emission scans were concatenated in MATLAB into an EEM matrix. Excitation and emission instrument correction factors were applied to the data to correct for the spectral variations in the lamp output, optics, gratings and detector response. These correction factors were supplied by the manufacturer. A quinine sulfate standard was measured periodically for a $335 \mathrm{~nm}$ excitation wave-

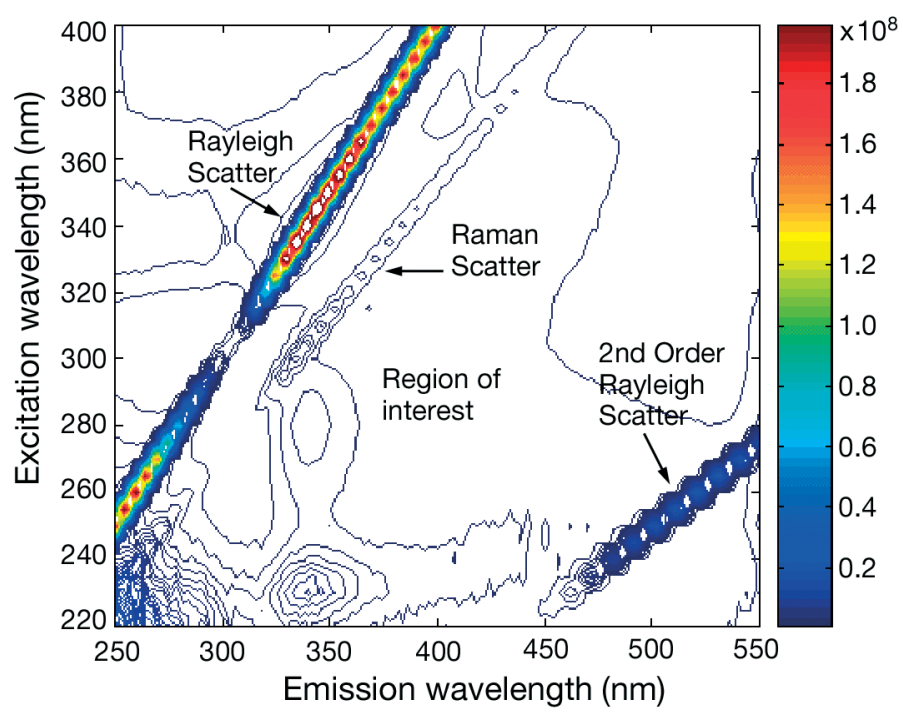

Fig. 2. Different regions of an excitation-emission matrix contour plot for a typical water sample. Scale: fluorescence intensity in counts $\mathrm{s}^{-1}$ 

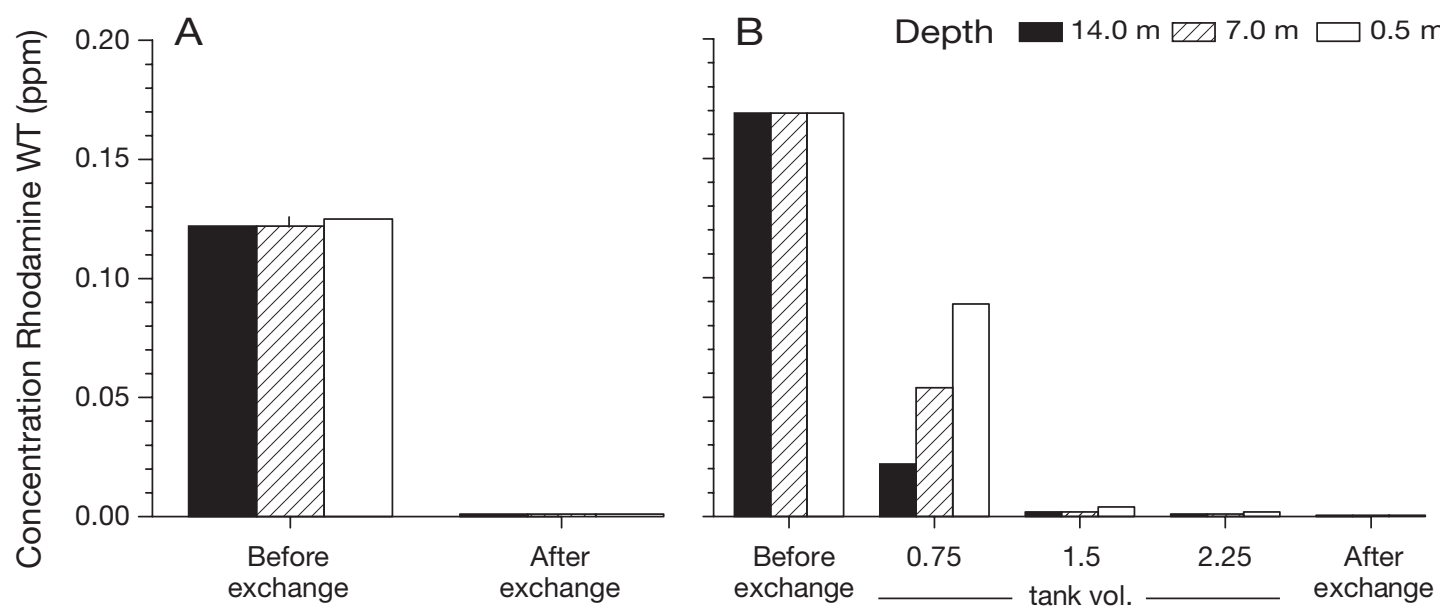

Fig. 3. Rhodamine WT concentrations at 0.5, 7.0 and $14.0 \mathrm{~m}$ depth strata in ballast tanks. (A) Before and after mid-ocean exchange of the starboard tank on the first transect (1 to 2 March 1999); (B) before, during and after mid-ocean exchange of the port tank on the second transect (13 to 14 March 1999)

length and the maximum fluorescence intensity of quinine sulfate was recorded. A normalization process was not applied to the data since variation in the fluorescence intensity of the quinine sulfate peak was relatively low ( $\leq 17 \%$ across all samples analyzed). EEMs were also recorded for MilliQ water in case water Raman scattering corrections were required.

\section{RESULTS}

\section{Dilution efficiency}

The concentration of Rhodamine WT added to the ballast tanks in the harbours was reduced by more than of $95 \%$ at all 3 of the ballast tank depth strata sampled for the mid-ocean exchanges on the voyage (see Fig. 3a and Taylor \& Bruce 1999). Time series sampling during the first exchange on the second transect (filling from the bottom), showed stratification of the dye in the tank after $75 \%$ of the tank volume had been pumped through the tank (Rhodamine WT dilution: $47 \%$ at $0.5 \mathrm{~m}, 68 \%$ at $7.0 \mathrm{~m}$, and $87 \%$ at $14.0 \mathrm{~m})$. Stratification of the dye was less apparent after 1.5 times the tank volume had been pumped through. At this stage the dye dilution was more than $95 \%$ at all 3 depth strata (Fig. 3b). The dye data from the exchanges using 3 times the tank volume resulted in exchange of more than $99 \%$ of the coastal water.

\section{Optical characteristics of the samples}

A significant amount of information is contained within each EEM spectra. These data are most readily presented as contour plots of the fluorescence intensity of paired excitation versus emission wavelengths (Fig. 4). The coastal water samples from this study typically show regions of higher fluorescence intensity compared to the mid-ocean sample. These were especially evident in the lower regions of the spectra for excitation wavelengths ranging from 220 to $340 \mathrm{~nm}$. The regions of higher fluorescence indicate the presence of different compounds based on the fluorescing properties of the water. For example, protein-like fluorescence is attributed to aromatic amino acids, either free or as protein constituents in the water (Coble 1996). Moreover, there are 2 types of protein-like fluo-

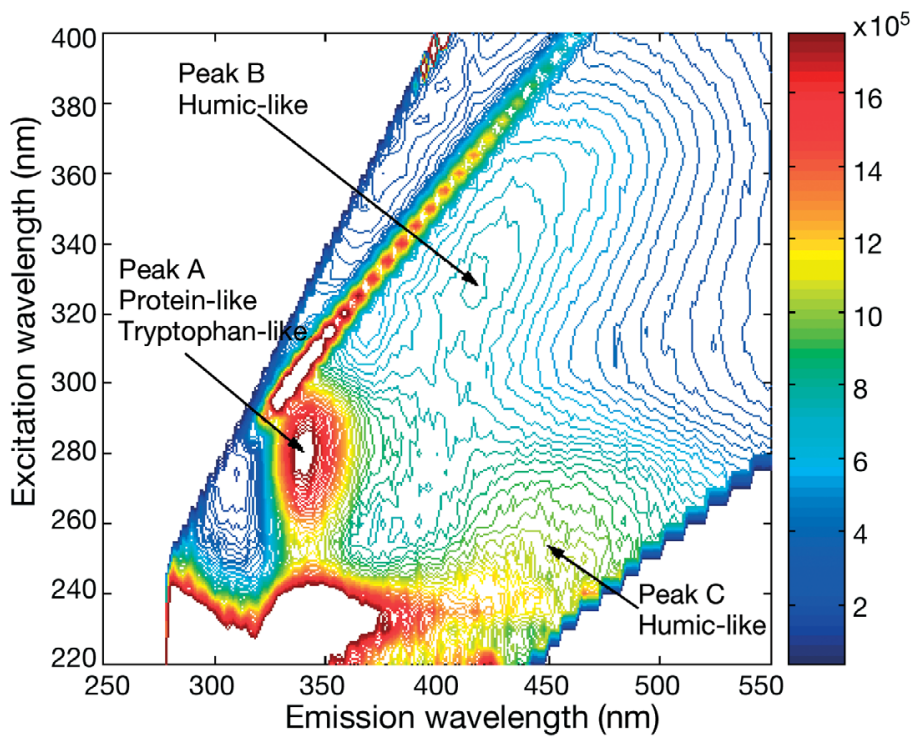

Fig. 4. Excitation-emission matrix contour plot for a typical coastal water sample, showing protein-like and humic-like fluorescence peaks. Scale: fluorescence intensity in counts $\mathrm{s}^{-1}$ 
rescence: tyrosine-like, which occurs at 300 to $305 \mathrm{~nm}$ from excitation wavelengths of 220 to $225 \mathrm{~nm}$ and 275 to $280 \mathrm{~nm}$; and tryptophan-like, which occurs at 340 to $350 \mathrm{~nm}$, from excitation wavelengths of 220 to $225 \mathrm{~nm}$ and 275 to $280 \mathrm{~nm}$. Fig. 4 shows a tryptophan-like peak typically observed in the samples from this study. Other peaks in the EEM spectra can be attributed to humic-like compounds. In general, humic-like emission fluorescence occurs at 420 to $460 \mathrm{~nm}$, from excitation wavelengths of 230 to $260 \mathrm{~nm}$ and 320 to $350 \mathrm{~nm}$ (Coble 1996).
A) 23.02.1999, Depth $=0.5 \mathrm{~m}$

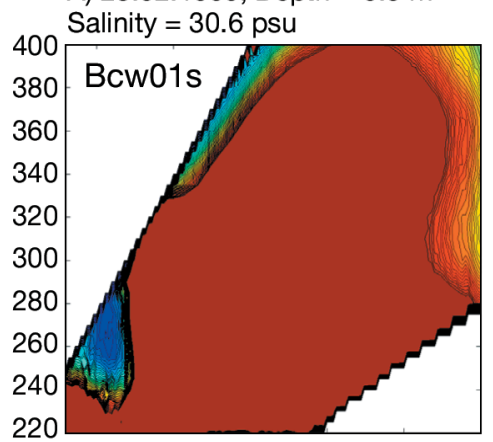

B) 23.02.1999, Depth $=5 \mathrm{~m}$

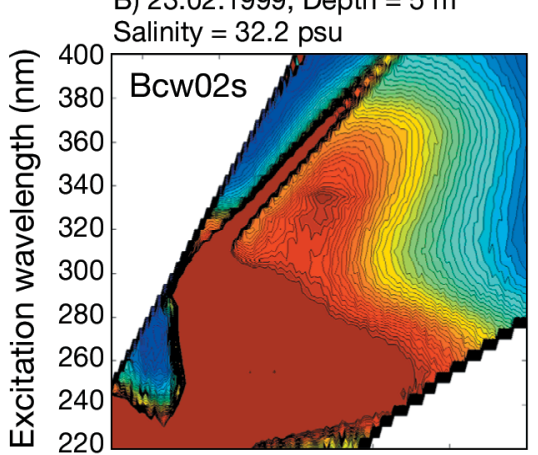

C) 23.02.1999, Depth $=10 \mathrm{~m}$

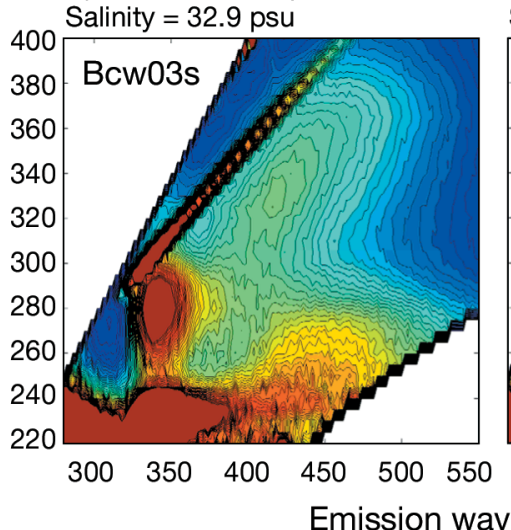

D) 01.03.1999

Salinity $=35.1 \mathrm{psu}$

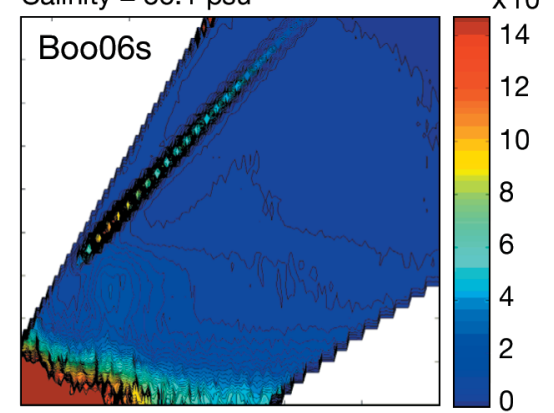

E) 02.03.1999

Salinity $=34.0 \mathrm{psu}$

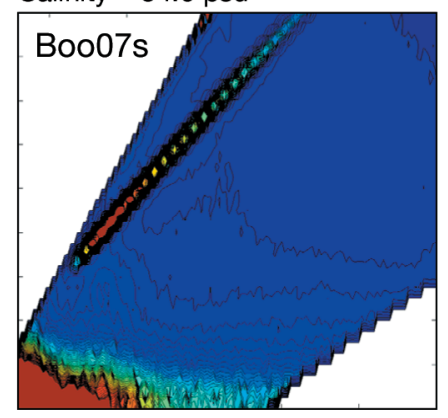

F) 02.03.1999

Salinity $=34.2 \mathrm{psu}$

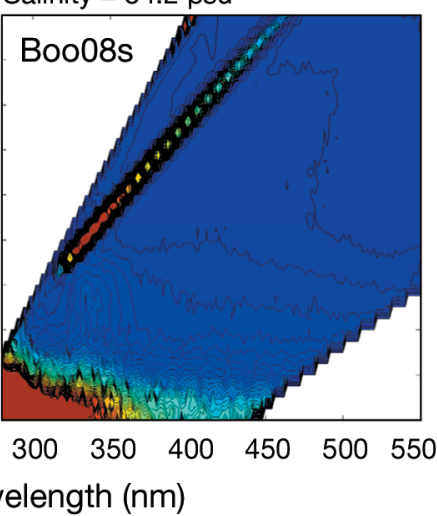

Fig. 5. Excitation-emission matrices for samples collected on the first transect of the voyage. (A-C) Coastal water samples collected from Kawasaki Harbour; (D-F) mid-ocean surface samples collected during the second exchange. Scale: fluorescence intensity in counts $\mathrm{s}^{-1}$

\section{Coastal water optical spectra}

A water column profile of EEM spectra for coastal water from Kawasaki Harbour was developed to characterize water at the port of origin and to determine if changes occurred after ballasting (Fig. 5A-C). At the surface $(0.5 \mathrm{~m})$, the fluorescence was greater than $15 \times 10^{5}$ counts $\mathrm{s}^{-1}$ at almost all wavelengths. Fluorescence intensity decreased with depth, reflecting an increase in salinity from $30.6 \mathrm{psu}$ at $0.5 \mathrm{~m}$ to $32.9 \mathrm{psu}$ at $10 \mathrm{~m}$.

The fluorescence of the water samples collected from Singapore Harbour also decreased as a function of depth; however, fluorescence intensity was generally lower at all depths compared to the Kawasaki Harbour samples. The region of highest fluorescence intensity was the protein-like peak with a maximum intensity of approximately $9 \times 10^{5}$ counts $\mathrm{s}^{-1}$ in the surface water sample. This intensity contrasts with the Kawasaki Harbour water that had a maximum fluorescence greater than $70 \times 10^{5}$ counts $\mathrm{s}^{-1}$ in the same region of the spectrum.

\section{Mid-ocean water optical spectra}

The EEMs of 3 mid-ocean surface water samples (Fig. 5D-F) taken during the exchange of the starboard tank ballast water uploaded in Kawasaki Harbour show a distinct difference in the optical characteristics of the mid-ocean water and the Kawasaki Harbour water. The mid-ocean EEMs clearly show higher salinity and lower fluorescence intensity than the coastal water samples. While little structure in the mid-ocean water fluorescence was present there was a peak in fluorescence around the protein-peak (excitation: $270 \mathrm{~nm}$; emission: $340 \mathrm{~nm}$, which was very small relative to the protein-like signature in the coastal water samples.

The 22 mid-ocean surface water sample EEMs from the ship's entire trackline were generally similar, as represented in Fig. 6. The optical signature of midocean samples consistently had low fluorescence intensity (typically less than $2 \times$ $10^{5}$ counts $\mathrm{s}^{-1}$ ) and little structure. The samples typically had a small proteinlike fluorescence; however, none of the 


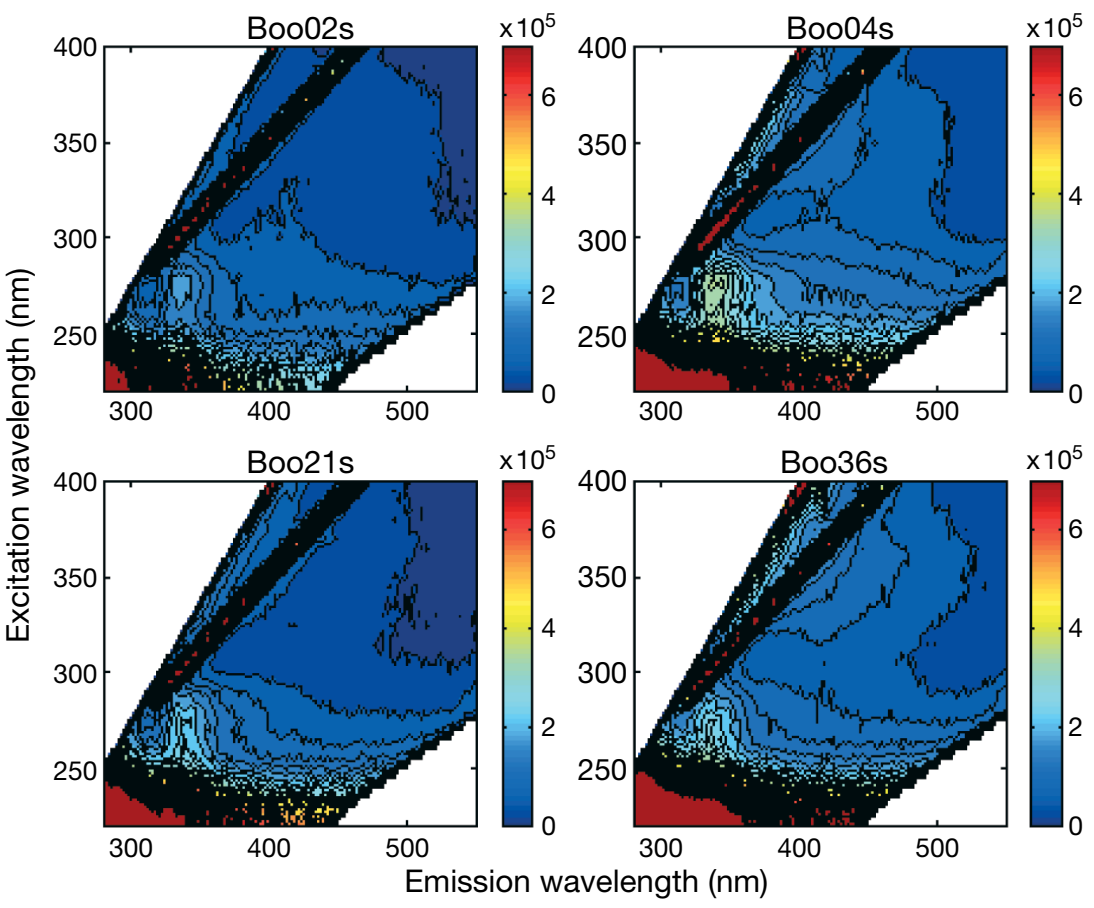

Fig. 6. Excitation-emission matrices for mid-ocean water samples collected throughout the voyage. Scale: fluorescence intensity in counts $\mathrm{s}^{-1}$, scaled to maximum fluorescence of $7 \times 10^{5}$ counts $\mathrm{s}^{-1}$. The sample locations can be found in Fig. 1 as follows: Boo02s $=2 ;$ Boo04s $=5 ;$ Boo21s $=7$; Boo36s $=10$ water to water in the ballast tanks shortly after ballasting and also before the mid ocean exchange and in the unexchanged control tank over the duration of the survey. The EEMs of samples taken at 3 depths $(0.5,7$ and $14 \mathrm{~m}$ ) in the ballast tanks several hours after ballasting in Kawasaki Harbour (24 February 1999) showed that the fluorescence signature in the tank was structurally similar but slightly more intense than the Kawasaki Harbour water at $10 \mathrm{~m}$ depth. Ballast tank samples taken 4 days later showed the fluorescence intensity of the protein like peak had increased slightly at all depths (from $\sim 1.9 \times 10^{6}$ to $\sim 2.2 \times 10^{6}$ counts $\mathrm{s}^{-1}$ ), which may have been due to the growth of bacteria in the tank or other biological activity such as decomposition of phytoplankton and zooplankton. Similarly, the fluorescence signature of the control tank (not exchanged) did not change significantly over the duration of the transect (Taylor \& Bruce 1999).

The EEMs of ballast tank samples from Tank $6 \mathrm{~S}$ on 28 February 1999 just before exchange was started were generally uniform and similar in fluorescence structure and intensity to the water from Kawasaki Harbour (compare Fig. 8A-C to Fig. 5C). The optical signature of ballast water several hours after completion of the exchange on 3 March 1999 were low and had very little structure(Fig. 8D-F). Note the exchange increased the salinity from $\sim 32.8$ to $34.2 \mathrm{psu}$. Moreover, the optical signature after exchange was similar to that of the mid-ocean surface samples collected during the exchange (Taylor \& Bruce 1999). The compounds containing fluorophores which contribute to the humic-like peaks were not present in the EEMs of the samples collected after the exchange. The EEMs of the exchanged ballast tank $4 \mathrm{~d}$ after the completion of the exchange remained low and similar to those at the end of the exchange, although there was a slight increase in the fluorescence intensity around the protein-peak, which suggests that some bacterial growth may have occurred in the tank over this period.

Table 1 summarizes the fluorescence intensity of the protein-like and $430 \mathrm{~nm}$ humic-like fluorescence peaks for coastal and mid-ocean water samples, as well as ballast water samples collected from the exchanged starboard tank, i.e. Tank 6S. The peak values were determined by selecting the maximum

was documented by comparing the EEMs of the coastal 
A) Emission scans at excitation wavelength $250 \mathrm{~nm}$ (Bcw03s and Boo02s)

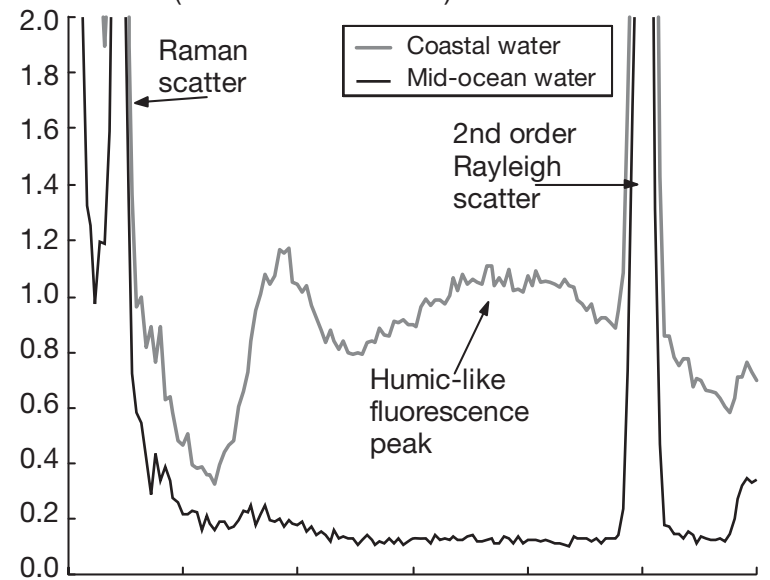

B) Emission scans at excitation wavelength $275 \mathrm{~nm}$ (Bcw03s and Boo02s)

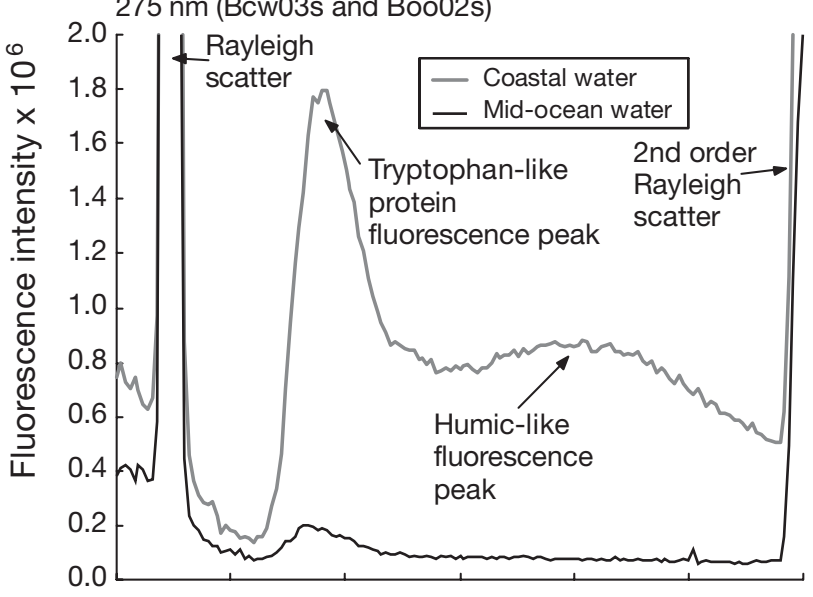

C) Emission scans at excitation wavelength $330 \mathrm{~nm}$ (Bcw03s and Boo02s)

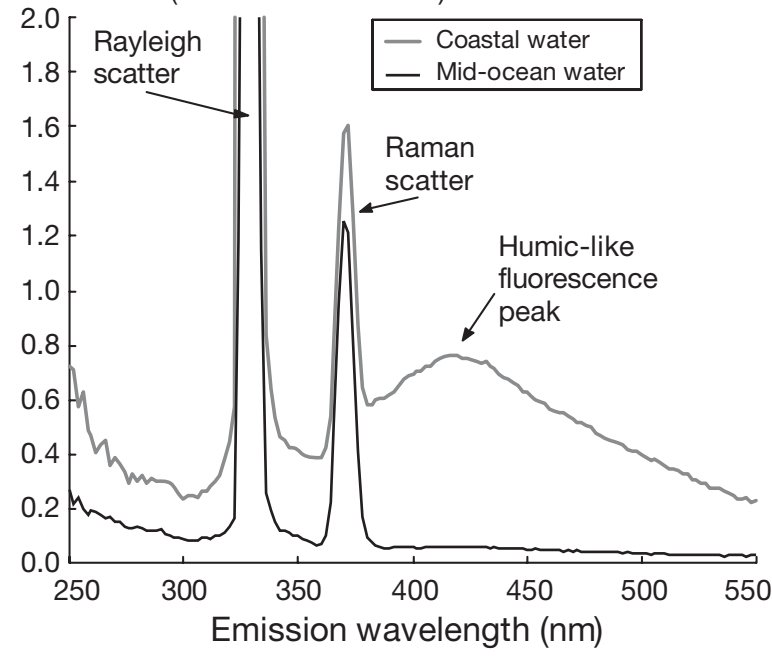

Fig. 7. Emission scans at (A) 250, (B) 275 and (C) $330 \mathrm{~nm}$ for coastal water samples collected at $10 \mathrm{~m}$ depth from Kawasaki Harbour, and for a mid-ocean water sample collected off the west coast of Japan fluorescence intensity in the region surrounding the peak that included a portion of the spectrum approximately $10 \mathrm{~nm}$ wide. The absolute magnitude of the fluorescence intensity of the ballast water samples ollected before the exchange was 5 to 10 times greater than the fluorescence intensity of the ballast water samples collected after the exchange.

The Raman peak value was also determined for these samples to serve as a reference point. The ratio of Raman value to the fluorescence peaks is presented in order to illustrate the differences between samples collected before and after the exchange. The humic and protein ratios ranged from 0.09 to 0.14 and from 0.28 to 0.62 , respectively, for all of the mid-ocean water samples. This was consistent with the values for the ballast water samples collected after the exchange, which had values ranging from 0.10 to 0.14 for the humic ratio and from 0.31 to 0.33 for the protein ratio. In contrast, the ballast water samples collected before the exchange had values ranging from 0.58 to 0.75 for the humic ratio and from 1.60 to 2.18 for the protein ratio

The changes in optical characteristics of the samples collected from the second transect (Singapore to New Plymouth, NZ) were similar to those observed for the first transect, even though the fluorescence intensities of the ballast water samples from Singapore Harbour were 2 to 3 times lower in magnitude than the fluorescence intensities of the samples from Kawasaki Harbour. Even so, the mid-ocean exchange on this transect reduced the fluorescence intensity and structure of the coastal water to that of the mid-ocean water. Thus, even though there were large differences in the fluorescence intensity of the 2 source waters, the fluorescence data clearly demonstrated the exchange of coastal waters for oceanic water.

\section{DISCUSSION}

The EEM spectra derived from the coastal water samples collected on the voyage showed a decreasing DOM fluorescence gradient with depth of the water column, with the highest fluorescence intensity in the lower salinity surface water. The coastal water samples also exhibited fluorescence peaks in 3 distinct regions: a protein-like (tryptophan-like) peak and 2 humic-like peaks. In contrast, the EEM spectra derived from the 22 mid-ocean samples collected throughout the voyage had fluorescence signatures that were low in intensity and consistently lacked fluorescence structure. Together these data confirm reports in the literature (e.g. Coble 1996, Coble et al. 2004) that DOM fluorescence is useful for distinguishing between water types. 


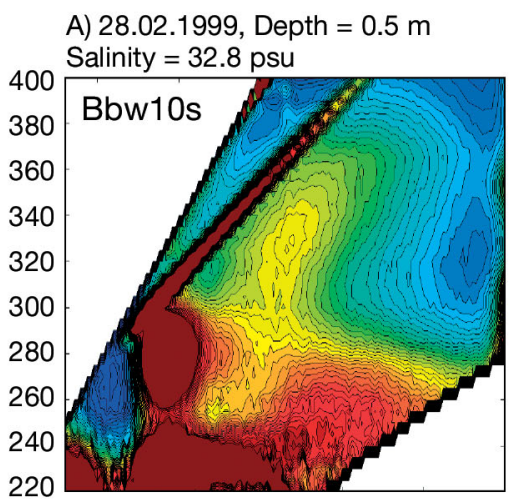

B) 28.02.1999, Depth $=7 \mathrm{~m}$ Salinity $=32.8 \mathrm{psu}$

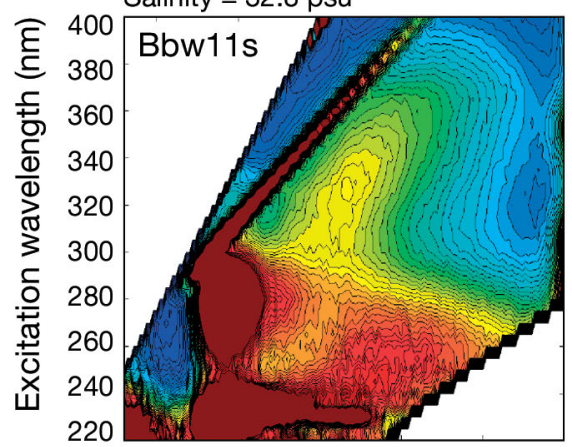

C) 28.02.1999, Depth $=14 \mathrm{~m}$ Salinity $=32.7 \mathrm{psu}$

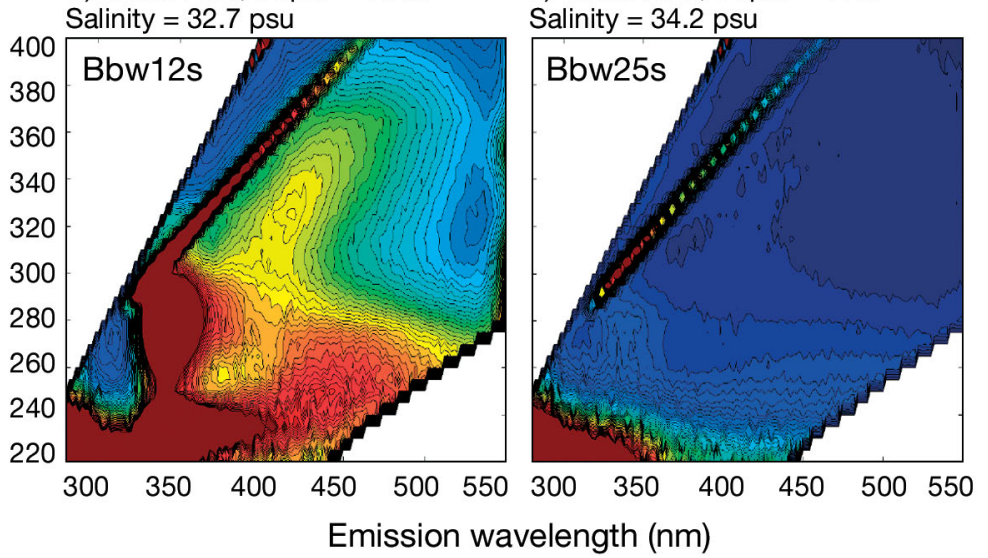

Fig. 8. Excitation-emission matrices for samples collected from 3 depths in starboard ballast Tank $6 \mathrm{~S}$ before exchange and several hours after exchange on first transect of voyage. Scale: fluorescence intensity in counts $\mathrm{s}^{-1}$
D) 03.03.1999, Depth $=0.5 \mathrm{~m}$

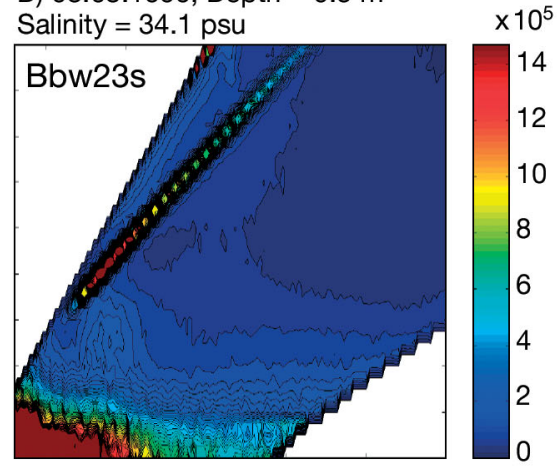

E) 03.03.1999, Depth $=7 \mathrm{~m}$ Salinity $=34.1 \mathrm{psu}$

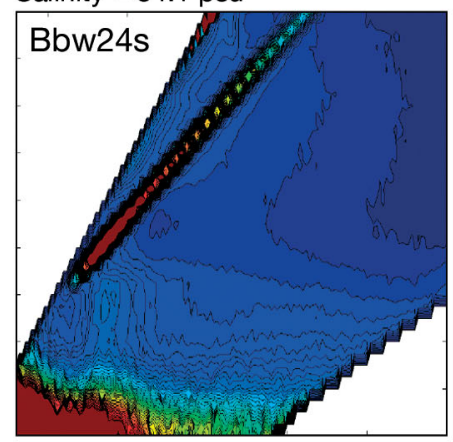

F) 03.03.1999, Depth $=14 \mathrm{~m}$ Salinity $=34.2 \mathrm{psu}$

in the fluorescence spectra of independently collected, depth-stratified ballast water samples varied slightly in fluorescence intensity. This variation was not always reflected in the corresponding salinity measurements and implies that ballast water stratification not detected on the basis of physical variables such as temperature and salinity may be detected by characterizing the optical signature. The sensitivity of fluorescence was further demonstrated by an apparent increase in fluorescence intensity in the protein region in ballast water samples collected after uptake. This increase in fluorescence intensity is probably due to decomposition of organisms or bacterial growth within the tanks.

In contrast to the subtle changes considered above, marked shifts in the optical signature of the ballast water were evident after mid-ocean exchange, which coincided with a >99\% reduction in the added dye concentration by the mid-ocean exchanges (Taylor \& Bruce 1999). The reduction in dye concentration is significant in that it confirmed that the ballast water was fully exchanged in mid-ocean.

Contrary to the change in dye concentrations and fluorescence signature, the salinity and biological data from the voyage were not found to be effective in estimating the efficiency of exchange (Taylor \& Bruce 1999). Salinity was ineffective due to the small differences between coastal and ocean water, imprecision in measurement, and the confounding influence of remnant river plumes in the offshore waters exchanged (Taylor \& Bruce 1999). Moreover, the exchange efficiency estimated from the biological data did not match well with the dye results, primarily due to the abundance

The sensitivity of florescence measurement for characterizing ocean waters was demonstrated in several ways in this data set. For example, there were clear changes in fluorescence intensity with depth in ports. In addition, the fluorescence signature of ballast water samples collected several hours after ballasting was generally consistent with the signature of coastal water samples collected at approximately the same depth at which the tanks were filled. Moreover, small changes and diversity of oceanic species that were added to the ballast tank during the exchange. Even so, the plankton data showed a marked decrease in phytoplankton and zooplankton abundance and a shift in the species composition from that originally uplifted from the harbours (Taylor \& Bruce 1999). The biological data also show that species richness in the exchanged water decreased approximately $55 \%$ compared with $<37 \%$ in the control tanks. Thus, it was difficult to correctly 


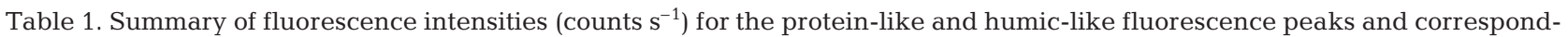
ing ratios to the Raman scattering peak, for various samples collected during the first transect of the voyage. CW: coastal water; BW: ballast water; MO: mid-ocean water. ${ }^{\text {a}}$ Sample codes Boo02s, Boo21s and Boo36s (Fig. 6) not in Table 1

\begin{tabular}{|c|c|c|c|c|c|c|c|}
\hline & Sample & $\begin{array}{l}\text { Sample code }^{a} \\
\text { in figures (Fig) }\end{array}$ & $\begin{array}{l}\text { Protein } \\
\text { peak }\end{array}$ & $\begin{array}{l}\text { Humic } \\
\text { peak }\end{array}$ & $\begin{array}{c}\text { Raman } \\
\text { peak }\end{array}$ & $\begin{array}{l}\text { Protein/ } \\
\text { Raman }\end{array}$ & $\begin{array}{l}\text { Humic/ } \\
\text { Raman }\end{array}$ \\
\hline \multirow[t]{3}{*}{ Kawasaki Harbour coastal water } & CW 01 & Bcw01s (5) & $7.92 \times 10^{6}$ & $4.84 \times 10^{6}$ & $2.95 \times 10^{6}$ & 2.68 & 1.64 \\
\hline & CW 02 & Bcw02s (5) & $4.92 \times 10^{6}$ & $1.51 \times 10^{6}$ & $1.59 \times 10^{6}$ & 3.09 & 0.95 \\
\hline & CW 03 & Bcw03s (5) & $1.90 \times 10^{6}$ & $7.82 \times 10^{5}$ & $1.03 \times 10^{6}$ & 1.86 & 0.76 \\
\hline \multirow[t]{10}{*}{ Mid-ocean water first transect } & MO 01 & & $3.23 \times 10^{5}$ & $1.03 \times 10^{5}$ & $9.69 \times 10^{5}$ & 0.33 & 0.11 \\
\hline & MO 02 & & $2.04 \times 10^{5}$ & $6.33 \times 10^{4}$ & $7.24 \times 10^{5}$ & 0.28 & 0.09 \\
\hline & MO 03 & & $3.67 \times 10^{5}$ & $7.30 \times 10^{4}$ & $7.59 \times 10^{5}$ & 0.48 & 0.10 \\
\hline & MO 04 & Boo04s (6) & $3.71 \times 10^{5}$ & $1.32 \times 10^{5}$ & $9.57 \times 10^{5}$ & 0.39 & 0.14 \\
\hline & MO 05 & & $1.75 \times 10^{5}$ & $6.25 \times 10^{4}$ & $4.83 \times 10^{5}$ & 0.36 & 0.13 \\
\hline & MO 06 & Boo06s (5) & $3.11 \times 10^{5}$ & $6.57 \times 10^{4}$ & $4.99 \times 10^{5}$ & 0.62 & 0.13 \\
\hline & MO 07 & Boo07s (5) & $2.02 \times 10^{5}$ & $6.15 \times 10^{4}$ & $7.14 \times 10^{5}$ & 0.28 & 0.09 \\
\hline & MO 08 & Boo08s (5) & $2.61 \times 10^{5}$ & $8.57 \times 10^{4}$ & $7.29 \times 10^{5}$ & 0.36 & 0.12 \\
\hline & MO 09 & & $2.32 \times 10^{5}$ & $6.82 \times 10^{4}$ & $6.82 \times 10^{5}$ & 0.34 & 0.10 \\
\hline & MO 10 & Boo10s (6) & $2.28 \times 10^{5}$ & $9.13 \times 10^{4}$ & $6.83 \times 10^{5}$ & 0.33 & 0.13 \\
\hline \multirow{6}{*}{$\begin{array}{l}\text { Before exchange ballast water } \\
\text { (Tank 6S) }\end{array}$} & BW 01 & & $2.16 \times 10^{6}$ & $7.78 \times 10^{5}$ & $1.35 \times 10^{6}$ & 1.60 & 0.58 \\
\hline & BW 02 & & $2.25 \times 10^{6}$ & $7.16 \times 10^{5}$ & $1.03 \times 10^{6}$ & 2.18 & 0.69 \\
\hline & BW 03 & & $1.18 \times 10^{6}$ & $5.41 \times 10^{5}$ & $9.39 \times 10^{5}$ & 1.26 & 0.58 \\
\hline & BW 10 & Bb1w10s (8) & $2.58 \times 10^{6}$ & $9.71 \times 10^{5}$ & $1.45 \times 10^{6}$ & 1.78 & 0.67 \\
\hline & BW 11 & Bb1w11s (8) & $2.89 \times 10^{6}$ & $9.82 \times 10^{5}$ & $1.38 \times 10^{6}$ & 2.09 & 0.71 \\
\hline & BW 12 & Bb1w12s (8) & $2.76 \times 10^{6}$ & $9.74 \times 10^{5}$ & $1.30 \times 10^{6}$ & 2.12 & 0.75 \\
\hline \multirow{3}{*}{$\begin{array}{l}\text { After exchange ballast water } \\
\text { (Tank 6S) }\end{array}$} & BW 23 & Bb1w23s (8) & $2.24 \times 10^{5}$ & $8.24 \times 10^{4}$ & $7.17 \times 10^{5}$ & 0.31 & 0.12 \\
\hline & BW 24 & Bb1w24s (8) & $3.43 \times 10^{5}$ & $1.40 \times 10^{5}$ & $1.03 \times 10^{6}$ & 0.33 & 0.14 \\
\hline & BW 25 & Bb1w25s (8) & $2.15 \times 10^{5}$ & $6.79 \times 10^{4}$ & $6.81 \times 10^{5}$ & 0.32 & 0.10 \\
\hline
\end{tabular}

assign the attrition in planktonic organisms to the expulsion of organisms by exchange, versus natural mortality. Taylor \& Bruce (1999) also conclude that the usefulness of coastal taxa as indicators of open ocean exchange is limited due to the cosmopolitan nature of many species.

One of the study objectives was to ensure that midocean ballast water exchange could be quantified using dye data. The dye study achieved this objective. It is less clear from the data whether the differences in the optical signatures and intensity before and after exchange could quantitatively support estimates of exchange efficiency. Although the fluorescence study was not designed to develop the highly precise fluorescence data necessary to quantify exchange efficiency, we explored its potential for estimating exchange efficiency. Estimating exchange efficiency based on florescence data can be problematic due to the many florescence and excitation wavelengths that could be used to derive efficiency estimates and the ability to precisely quantify fluorescence intensity of the naturally occurring DOM. Moreover, estimates of exchange efficiency using natural fluorescence assumes the measured fluorescence is derived from the same or very similar compounds, which while true at a general level, is not explicitly accurate due to the complex nature of the organic matter that contributes to the fluorescence signature and the level of analytical precision achieved by the study. Recognizing these limitations, the large difference between the coastal and open ocean fluorescence intensity was used to estimate exchange efficiency for comparison with the dye data. The data in Fig. 7 suggests that the peak fluorescence intensity at the 250 and $275 \mathrm{~nm}$ excitation lines was reduced by approximately $90 \%$ by the exchange. Exchange efficiencies calculated from the average peak protein and humic fluorescence intensities before and after exchange (Table 1) suggest an exchange efficiency of 88 and $90 \%$, respectively. Even though the relative precision derived from these samples is moderate $(\sim 25 \%)$, the exchange efficiency estimated from the fluorescence data is reasonably similar to that derived from the highly precise dye data.

These findings support our hypothesis that natural fluorescence can be used to verify exchange. However, further studies are necessary in order to ensure the robustness and defensibility of the method as a verification method. Among these are identification of appropriate instrumentation, sample turn around times, and verification protocols. Moreover, the ability to identify a small set of wavelengths, rather than use the entire EEM spectra for verification, suggests that optical verification could be conducted without the use of sophisticated bench scale laboratory instruments.

One of the concerns for our study design was the stability of the optical signature in the ballast tanks and 
the possibility of changes during shipment. Given the need for a highly controlled laboratory environment for the EEM analysis, time series studies to test stability could not be conducted on board the vessel. However, the fluorescence signatures of independent water samples collected from multiple depths in the unexchanged and exchanged ballast tanks over the duration of the transects (e.g. $12 \mathrm{~d}$ on the first transect) provide evidence for fluorescence stability. Likewise, the fluorescence of exchanged ballast water sampled from multiple depths over time was consistent and only showed small changes in the protein like area of the spectra. These data further suggest that the optical signature of the water loaded into the ballast tanks is relatively stable over periods typical of ocean voyages, an important factor when considering this method as a means of verifying mid-ocean exchange. The changes in these spectra also suggest this spectral region may not be the most appropriate area to use for verification.

It is also possible that post-collection changes in the fluorescence characteristics of the samples occurred during storage on board the vessel and subsequent shipping. The concern is that biological activity after the samples are taken could change the fluorescence signature, thereby making it difficult to distinguish between the original signature and any subsequent changes. This concept was considered during the design of this study and points to one of the important issues surrounding any verification method, minimizing changes and the time interval between collection and analysis. The fact that EEMs of independent samples taken over several days from multiple depths did not change is encouraging and points to the need for verification methods that minimize the introduction of potential sampling and handling artifacts. One way to control for these concerns is to take advantage of in situ fluorescent measurements. Such measurements would also provide practical convenience by enabling rapid shipboard measurements and reduce the costs of the analysis.

\section{CONCLUSIONS}

A voyage on a trans-Pacific chemical carrier MT 'Iver Stream' confirmed that optical characteristics of seawater could be used to verify the compliance of ships with mandatory international ballast water exchange requirements. The UV fluorescence of organic matter in seawater, expressed through high resolution EEM spectra and selected areas of the fluorescence spectra, readily discriminates between coastal and mid-ocean water. The lack of optical signatures in mid-Pacific water is significant for the hypothesis that optical characteristics of water can be used to verify ballast water exchange. We would expect this to hold generally true of other oceans. This, coupled with the relatively large and optically distinct fluorescence structure of coastal waters, supports the hypothesis that fluorescence based methods have great potential to verify midocean ballast water exchange.

Unfortunately, the nature of this study did not allow us to address questions on the best way to conduct verifications of open ocean exchange. It is clear, however, that any verification procedure must be completed quickly (i.e. $<1 \mathrm{~h}$ ), accurately, preferably onboard the vessel to minimize shipping delays, and at reasonable costs. It is also clear that collecting samples for analysis using highly specialized laboratory instruments and methods will not be appropriate for exchange verification. The data from this study also suggested that full EEMs are not necessary for verification; 1 or 2 wavelengths may suffice, as considered by Murphy et al. 2004. Moreover, the data from this study suggest that short delays in performing high resolution analyses, while undesirable, will not affect the optical signature of the water if the sample is stored properly.

In concept, the requirements for rapid low cost verification could be met by field instruments that are transported and deployed by 1 or 2 individuals. There are currently several commercially available field instruments based on florescence techniques which may be useful for optical based verification of midocean exchange. However, in a regulatory environment, the methodology must have low potential for data ambiguity, be accurate/precise, and have a low chance of sample contamination or sample degradation. Thus, instrumentation specifically developed or used for verification on board vessels must undergo rigorous testing to ensure that the data is appropriate and defensible for expected regulatory requirements. The availability of portable field instrumentation will make the optical verification of ballast water exchange relatively straight forward, rapid, and cost effective.

Acknowledgements. Staff from both Cawthron and Battelle contributed to this research, in particular: Lincoln MacKenzie, Tim Dodgshun, Cameron Hay, Wendy Gibbs, Henry Kaspar and Rod Asher of Cawthron, and Karen Foster and Scott Macomber of Battelle. Bob Chen and Steve Rudnick of the University of Massachusetts, Boston, provided invaluable assistance in analysis and discussion of the EEM data. Sincere thanks to Vroon BV, Ship managers, The Netherlands, for permission to travel aboard the MT 'Iver Stream'. Thanks also to Pieter van Leeuwen of Waterfront Shipping Co. Ltd, Vancouver, Stephen Bull of Hooker Pacific, New Plymouth and K. Awane of ALL Barwill Agencies, Japan, for their invaluable assistance prior to and during the voyage. This research would not have been possible without the generous assistance of the captain, officers, and crew of the MT 'Iver Stream'. This research was funded by the New Zealand Ministry of Fisheries. We also thank the peer reviewers, whose comments greatly improved the presentation and content of the paper. 


\section{LITERATURE CITED}

Carlton JT, Reid DM, Leeuwen H (1995) Shipping study - The role of shipping in the introduction of nonindigenous aquatic organisms to the coastal waters of the United States (other than the Great Lakes) and an analysis of control options. Final report from the Maritime Studies Program, Williams College, Mystic, CT, to the US Coast Guard, CG-D-11-95. Government Accession Number AD-A294809

Coble P (1996) Characterization of marine and terrestrial DOM in seawater using excitation-emission matrix spectroscopy. Mar Chem 51:325-346

Coble P, Brophy M (1994) Investigation of the geochemistry of dissolved organic matter in coastal waters using optical properties. SPIE Vol 2258, Ocean Optics XII, p 377-389

Coble P, Hu C, Gould RW, Chang G, Wood AM (2004) Colored dissolved organic matter in the coastal ocean. Oceanography 17:50-59

Harvey M, Gilbert M, Gauthier D, Reid D (1999). A preliminary assessment of risks for the ballast water-mediated introduction of nonindigenous marine organisms in the Estuary and Gulf of St. Lawrence. Can Tech Rep Fish Aquat Sci 2268

Hay C, Tanis D (1998) Mid ocean ballast water exchange: procedures, effectiveness and verification. A report prepared for the New Zealand Ministry of Fisheries. Cawthron Report No. 468. Cawthron Institute, Nelson

International Maritime Organization (2004) International convention for the control and management of ships ballast water \& sediments, 2004. International Maritime Or-

Editorial responsibility: Victor de Jonge (Contributing Editor), Haren, The Netherlands ganization, London. Available at: www.imo.org/home. asp?topic_id=583\&doc_id=2689

Kirk J (1983) Light and photosynthesis in aquatic ecosystems. Cambridge University Press, New York

Murphy K, Boehme J, Coble P, Cullen J and 5 others (2004) Verification of mid-ocean ballast water exchange using naturally occurring coastal tracers. Mar Poll Bull 48: 711-730

National Research Council (1996) Stemming the tidecontrolling introductions of nonindigenous species by ship's ballast water. National Academy Press, Washington, DC

Rigby G, Hallegraeff G (1994) The transfer and control of harmful marine organisms in shipping ballast water: behavior of marine plankton and ballast water exchange trials on the MV 'Iron Whyalla'. J Mar Environ Eng 1: 91-110

Ruiz GM, Fofonoff PW, Carlton JT, Wonham MJ, Hines AH (2000) Invasion of coastal marine communities in North America: apparent patterns, processes, and biases. Annu Rev Eco Syst 31:481-531

Taylor M, Bruce E (1999) Mid ocean ballast water exchange: shipboard trials of methods for verifying efficiency. Cawthron Report No. 524, Cawthron Institute, Nelson

USCG (United States Coast Guard) (2001) Report to Congress on the voluntary national guidelines for ballast water management. US Coast Guard, Washington, DC

USCG (2004) Mandatory ballast water management program for US waters: final rule. Federal Register, Vol. 69, No. 144. USCG-2003-14273

Vitousek PM, Mooney HA, Lubchenco J, Melillo JM (1997) Human domination of Earth's ecosystems. Science 277:494-499

Submitted: March 31, 2005; Accepted: June 26, 2006

Proofs received from author(s): January 29, 2007 